\title{
CORRIGENDUM
}

\section{Impact of HLA mismatch direction on outcomes after umbilical cord blood transplantation for hematological malignant disorders: a retrospective Eurocord-EBMT analysis}

R Cunha, P Loiseau, A Ruggeri, G Sanz, G Michel, AP lori, G Socié, W Arcese, A Picardi, C Dias de Heredia, B Rio, F Locatelli, TA O'Brien, I Yakoub-Agha, MA Diaz, N Milpied, H Bittencourt, MP Souza, M Aljurf, D Charron, K Boudjedir, M Labopin,

E Gluckman and V Rocha

Bone Marrow Transplantation (2014) 49, 864; doi:10.1038/bmt.2014.82

Correction to: Bone Marrow Transplantation (2014) 49, 24-29; doi:10.1038/bmt.2013.120; published online 19 August 2013

Since the publication of this article, the authors have noticed that AP lori's name was misspelt. The correct name is shown above.
The authors would like to apologize for any inconvenience caused. 